\title{
ANALYZING TECHNICAL COMPETENCY, RELATIONAL CAPABILITIES AND COGNITIVE ABILITIES ON CUSTOMER SATISFACTION AT DISTRIBUTOR COMPANIES IN INDONESIA
}

\author{
Mohamad Firdaus ${ }^{1}$, Nila K. Hidayat ${ }^{1}$, Firdaus Basbeth ${ }^{2}$ \\ ${ }^{1}$ Swiss German University, Tangerang, Indonesia \\ ${ }^{2}$ IPMI Business School, Jakarta, Indonesia
}

\author{
Article Information \\ Received: 26 July 2021 \\ Accepted: 13 September 2021 \\ Published: 15 October 2021 \\ DOI: $10.33555 / \mathrm{embm} . v 9 i 1.188$ \\ Corresponding Author: \\ Mohamad Firdaus \\ Tangerang, Indonesia \\ Email: mohamad.firdaus@student.sgu.ac.id \\ ISSN 2338-8854 \\ eISSN 2620-9918
}

\begin{abstract}
In the current era of globalization, business competition is getting tougher and as a market leader, companies must always maintain their performance and improve their performance, so that customer satisfaction is always maintained. Especially the performance of mechanical services to customers whose performance must be maintained. Main problem faced by PT United Tractors heavy equipment service division is a decrease in customer satisfaction. The decrease in satisfaction is thought to be caused by a decrease in mechanics technical competence, the lack of mechanical ability to maintain good relationships (relational capability) with customers and the ability to identify problems (cognitive abilities) faced by customers. The purpose of this research is to analyze the impact of technical competency, relational capability and cognitive ability toward customer satisfaction and to analyse the impact of customer satisfaction toward customer loyalty. As a quantitative research, the study distributed questionnaires to 200 respondents who are customers who used mechanics services, so that it can be seen what variables have a significant impact on customer satisfaction. The findings of this study are that cognitive ability and technical competency have a significant impact on customer satisfaction, while relational capability has no significant impact on customer satisfaction. The influence of customer satisfaction on customer loyalty has a significant impact.
\end{abstract}

Keyword: Cognitive Abilities, Customer Loyalty and Dynamic Capability, Customer Satisfaction, Relational Capabilities, Technical Competency 


\section{Introduction}

In the current era of globalization, business competition is getting tougher and as a market leader, companies must always maintain their performance and improve their performance, so that customer satisfaction is always maintained. To maintain and improve performance according to the times, the company's ability must also be adjusted based on customer satisfaction. According to Ilieska (2013), customer satisfaction results or customer satisfaction index (CSI) can help to identify important customer requirements. Identification of the specific customer requirements for achieving satisfaction is useful at a very fundamental level. Every 2 years PT United Tractor's customer satisfaction is measured using the services of an independent agency and the measurement results become a reference for the service division in improving its quality of mechanics. The phenomena in terms of service quality of Mechanics on the Customer Satisfaction Index (CSI) in 2019 compared to 2017 survey, the results tend to decrease.

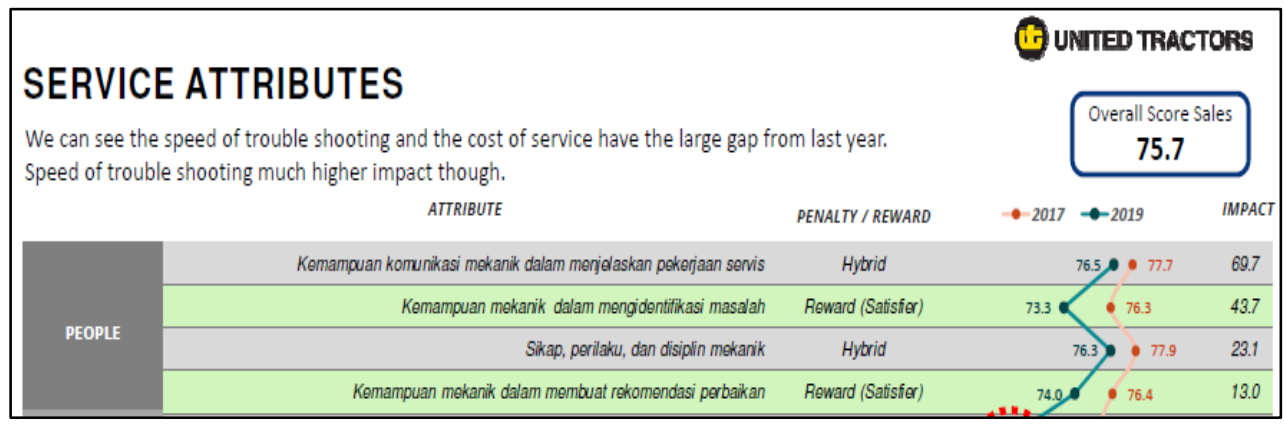

Figure 1. Customer Satisfaction Study 2019

Source: Ipsos, PT United Tractors CSI Study 2019

According to Ngo and Nguyen (2016), One of the important antecedents in customer loyalty is customer satisfaction, besides that customer satisfaction also mediates the effect of service quality on customer loyalty. Good service quality will make customers satisfied and customers will be loyal to the product provider. This good service quality needs to be explored more deeply what dimensions or indicators are appropriate to deal with in this era, given the dynamic character and perceptions of customers. So it is very important to know the dynamic capability of mechanics in providing the best service quality.

According to Flint et al. (2011), it is very possible that we need multiple interpretations of future customer needs, expectations, and requirements, and for mitigation we need anticipation capability or dynamic capability. Based on the results of the hypothesis perceived customer value anticipation positively affects customer satisfaction.

According to Adner and Helfat (2003), it is very important to pay attention to dynamic managerial abilities, because they reflect human capital, managerial social capital, and managerial cognition. This is needed so that the organization always exists in business competition and faces changing external conditions. To deal with business growth and maintain customer satisfaction, it is necessary to review the appropriate abilities that are compatible with Dynamic Managerial Capabilities (DMC) will effect on customer satisfaction. Author tries to explore the appropriate variables with the DMC whether it can affect customer satisfaction. 
Here are some of the variables that will be explored in relation to customer satisfaction:

1. Technical Competency (represents Managerial Human Capital in DMC).

2. Relational Capabilities (represents Managerial Social Capital in DMC).

3. Cognitive abilities (represent Managerial Cognition in DMC).

Based on the explanation information above, it is very clear that the main problem faced by PT United Tractors heavy equipment service division is a decrease in customer satisfaction index survey results. The decline in the survey results is a concern for service divison to be followed up. The decrease in satisfaction is thought to be caused by a decrease in mechanics technical competence, the lack of mechanical ability to maintain good relationships (relational capability) with customers and the ability to identify problems (cognitive abilities) faced by customers. This condition will affect customer loyalty in the long term. In this heavy equipment service division, there has never been a measurement of the impact of a lack of mechanical competence and customer satisfaction on loyalty, so this needs to be done.

The goal of this study are to analyze the impact of technical competency toward customer satisfaction, to analyze the impact of relational capabilities mechanics toward customer satisfaction, to analyze the impact of cognitive abilities mechanics toward customer satisfaction and to analyze the impact of customer satisfaction toward customer loyalty.

\section{Literature Review}

\subsection{Customer Satisfaction}

From the three literatures ((Ajao et al., 2012), (Angelova and Zekiri, 2011), (Hamzah and Shamsudin, 2020)), it is summarized that definition of customer satisfaction is customer evaluation of a product or service in which there is service quality to the response of customer fulfillment with the expected standard output in accordance with customer expectations or in other words, no complaints.

Based on the explanation above, the dimensions used in customer satisfaction consist of:

1. Less complaints: Conformity of the quality of goods and services with customer expectations.

2. Service quality: Service quality that is delivered can meet or exceed customer's expectations are mainly influenced by customer's prior expectations.

3. Fullfilment response: The act of completing the customer's will and know what the customer wants (expectation) and follow up on customer evaluation results.

\subsection{Customer Loyalty}

From the three literatures ((Bobâlcă et al., 2012), (Ngo and Nguyen, 2016), (Ajao et al., 2012)), it is summarized that the definition of customer loyalty is an emotional bond to a company for its experience with the company, which is shown in attitudes or behavior in the form of repeat orders, recommendations and retention.

Based on the explanation above, the dimensions used in customer loyalty consist of :

1. Repeat order: Customer to continue to buy products.

2. Recomendation: Customer saying positive things about the company to others, recommending the company or service to others.

3. Retention: Customer to continue to buy one company's products both with his commitement to the company.

\subsection{Technical Competency}

From the three literatures ((Lambert et al., 2014), (Yaman et al., 2015), (Khuzainey et al., 2020)), it is summarized that the 
definition of technical competency is the complete ability to carry out work to produce the best service performance which includes skills, knowledge and work attitudes.

Based on the explanation above, the dimensions used in technical competecy consist of :

1. Skill: Mechanics technical abilities in carrying out repair and maintenance of heavy equipment.

2. Knowledge: Theoretical mechanics knowledge regarding heavy equipment repair and maintenance.

3. Responsiveness: Mechanics abilities does something well when performing.

\subsection{Relational Capabilities}

From the two literatures ((Smirnova et al., 2011), (Ngugi et al., 2010)), it is summarized that definition of relational capabilities is the ability to build relationships that can be done for one another that has an impact on benefits through the integration of knowledge, values and culture.

Based on the explanation above, the dimensions used in relational capabilities consist of :

1. Sharing knowledge: Interaction to sharing knowledge and expertise.

2. Sharing value: Interaction to sharing values.

3. Sharing culture: Interaction to sharing culture.

\subsection{Cognitive Abilities}

From the three literatures ((Wang et al., 2017), (Macnamara et al., 2011), (Denis and Gilbert, 2012) ), it is summarized that the definition of cognitive abilities is an individual's capacity to understand something complex and analyze this information so that it is able to produce a relevant conclusion.
Based on the explanation above, the dimensions used in cognitive abilities consist of:

1. Level of understanding: Capacity to understand complex ideas.

2. Problem identification skill: Capacity to identification problem.

3. Capacity to learn: Capacity to get something new and adaptation to change.

Formulation of the problem is used as the beginning of the formulation of hypotheses, both of which of course require literature so that the literature will facilitate understanding of the findings to be strengthened or understanding of principles (Toledo, Flikkema and Toledo-Pereyra, 2011). The authors suspect that :

$H_{1}$ : Technical Competency has a significant impact on Customer Satisfaction

$\mathrm{H}_{2}$ : Relational Capabilities has a significant impact on Customer Satisfaction

H3: Cognitive Ability has a significant impact on Customer Satisfaction

$\mathrm{H}_{4}$ : Customer Satisfaction has a significant impact on Customer Loyality

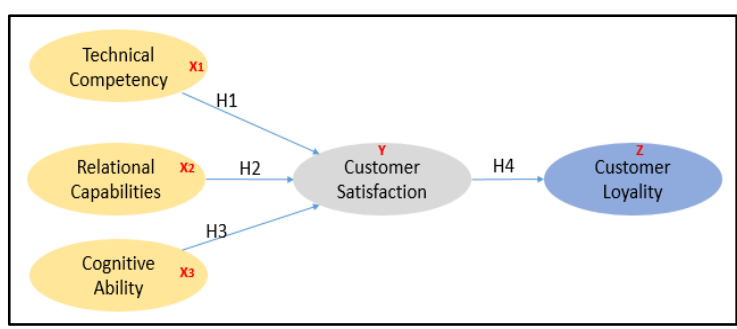

Figure 2. Connection Variable

\section{Research Method}

The objective of a descriptive study is to obtain data that describes the topic of interest. Descriptive studies are often designed to collect data that describe characteristics of objects (such as persons, organizations, products, or brands), events, or situations. Descriptive research is either quantitative or qualitative in nature (Sekaran and Bougie, 2016). 
The type of research method used is descriptive study. The author chose this method because it uses a factual, systematic, and accurate approach. This study describes the service quality provided by mechanics. The author wants to know more deeply about the phenomenon of the customer satisfaction impact caused by competency, relational capability and cognitive ability of mechanics. In this study, data collection was carried out using electronic survey sites such as survey application and this research using probability sampling which is simple random sampling Random sampling or probability sampling means that each element in a population has an equal and independent chance of being selected in the sample. The selection or rejection of one element does not affect the inclusion or exclusion of another. The authors takes the sample size 200 respondents. The first part of the questionnaires consists with the demographic questions and the second part of the questionnaires consist with the research questions and using likert scale from one to five.

This research analyzed the data using SPSS to test the validity and reliability of each variable and Cross Tab Analysis. The validity test used the Pearson's product moment correlation method, while the reliability test used Cronbach's alpha. The author will use PLS - SEM as an application to see the relationship between variables, then the results of the relationship between these variables are analyzed using t-values for assessment one side 1,65 at the 0.05 significance level (Hair et al., 2014).

\section{Result and Discussion}

The majority of respondents come from the Mining sector as much as $70 \%$ and come from UT customers who have known UT for 11 - 15 years, namely $27 \%$. The majority of respondents come from UT customers who have an interval of using UT mechanics services once a month which is as much as $34 \%$ and type job of Troubleshooting as much as $42 \%$. For Descriptive Statistic Analysis as showed figure 3 , the results of the analysis on IBM SPSS Statistics version 25 show that most of the respondents rated Customer loyalty as having the highest value, especially for repeat orders for mechanics services with a mean of 4.58 , while the comparison between recommendation and retention turned out to be that customers prefer to provide recommendations rather than retention with a mean 4.4 versus 4.3 .

Relational Capability is an important concern, especially sharing value with a mean of 4.46, while sharing knowledge is the lowest rating from customers with a mean of 4.20. However, here there is respondent dissatisfaction with the knowledge sharing of UT mechanics, so they strongly disagree with the relational capability of UT mechanics. Customer Satisfaction which is the focus of respondents is on service quality compared to other indicators, namely with a mean of 4.43. Meanwhile, the lowest indicator is found in less complaints, with a mean of 4.35. It can also be interpreted that customers will feel more satisfied if the Cognitive Ability has a mean that is spread evenly across each indicator, while the highest mean is 4.44 , namely Capacity to learn and the lowest is 4.33. For independent variable cognitive ability becomes the second priority after relational capability variable, but here the difference is the lowest rating between cognitive ability and relational capability 4.33 versus 4.20. It can be interpreted that cognitive ability is better than relational capability. 
Table 1. Descriptive Statistics

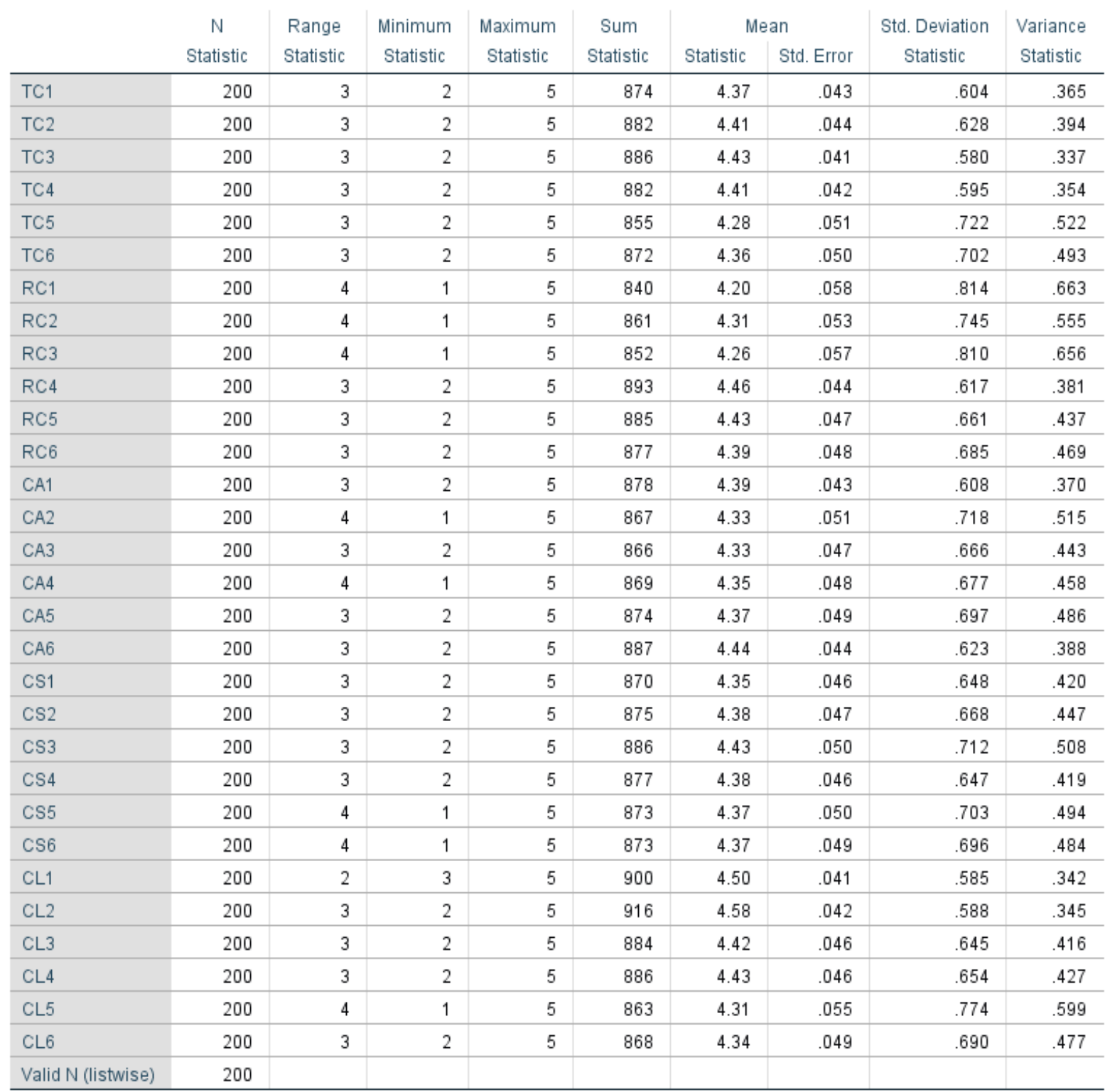




\section{Validity and Reliability Test}

Based on the result in Table 2, this study can be considered as valid and reliable because validity testing based on the value of the $r$
Table used based on the number of $\mathrm{N}=200$, the value of the $5 \%$ significance level is 0.138 and for reliability test the result more than 0.9 for $\alpha=0.6$.

Table 2. Result Test Validity and Reliability Source: Data Analysis using SPSS

\begin{tabular}{|c|c|c|c|c|c|c|c|c|}
\hline \multirow{2}{*}{$\begin{array}{l}\text { Variable } \\
\text { Name }\end{array}$} & \multirow{2}{*}{\multicolumn{2}{|c|}{$\begin{array}{l}\text { Observed } \\
\text { Variables }\end{array}$}} & \multicolumn{3}{|c|}{$\begin{array}{c}\text { Validity* } \\
\text { (Pearson's correlation } \\
\text { Product Moment) }\end{array}$} & \multicolumn{3}{|c|}{ Reliability } \\
\hline & & & r-value & r-table & Result & $\begin{array}{c}\text { Cronbacch's } \\
\text { Alpha } \\
\text { Result } \\
\end{array}$ & $\alpha$ & Result \\
\hline \multirow{6}{*}{$\begin{array}{l}\text { Technical } \\
\text { Competency }\end{array}$} & \multirow{2}{*}{ Skill } & $\mathrm{TC} 1$ & 0,765 & \multirow{30}{*}{0,138} & Valid & 0,973 & \multirow{30}{*}{0,6} & Reliable \\
\hline & & $\mathrm{TC} 2$ & 0,690 & & Valid & 0,973 & & Reliable \\
\hline & \multirow{2}{*}{ Knowledge } & TC3 & 0,686 & & Valid & 0,973 & & Reliable \\
\hline & & $\mathrm{TC} 4$ & 0,712 & & Valid & 0,973 & & Reliable \\
\hline & \multirow{2}{*}{ Responsiveness } & TC5 & 0,762 & & Valid & 0,973 & & Reliable \\
\hline & & TC6 & 0,720 & & Valid & 0,973 & & Reliable \\
\hline \multirow{6}{*}{$\begin{array}{l}\text { Relational } \\
\text { Capabilities }\end{array}$} & \multirow{2}{*}{$\begin{array}{c}\text { Sharing } \\
\text { Knowledge }\end{array}$} & $\mathrm{RC} 1$ & 0,770 & & Valid & 0,973 & & Reliable \\
\hline & & $\mathrm{RC} 2$ & 0,800 & & Valid & 0,973 & & Reliable \\
\hline & \multirow{2}{*}{$\begin{array}{l}\text { Sharing } \\
\text { Value }\end{array}$} & $\mathrm{RC} 3$ & 0,766 & & Valid & 0,973 & & Reliable \\
\hline & & $\mathrm{RC} 4$ & 0,755 & & Valid & 0,973 & & Reliable \\
\hline & \multirow{2}{*}{$\begin{array}{l}\text { Sharing } \\
\text { Culture }\end{array}$} & RC5 & 0,700 & & Valid & 0,973 & & Reliable \\
\hline & & RC6 & 0,752 & & Valid & 0,973 & & Reliable \\
\hline \multirow{6}{*}{$\begin{array}{l}\text { Cognitive } \\
\text { Ability }\end{array}$} & \multirow{2}{*}{$\begin{array}{c}\text { Level of } \\
\text { understanding }\end{array}$} & CA1 & 0,751 & & Valid & 0,973 & & Reliable \\
\hline & & $\mathrm{CA} 2$ & 0,787 & & Valid & 0,973 & & Reliable \\
\hline & $\begin{array}{c}\text { Problem } \\
\end{array}$ & CA3 & 0,828 & & Valid & 0,972 & & Reliable \\
\hline & Skill & CA4 & 0,788 & & Valid & 0,973 & & Reliable \\
\hline & Capacity to & CA5 & 0,787 & & Valid & 0,973 & & Reliable \\
\hline & Learn & CA6 & 0,754 & & Valid & 0,973 & & Reliable \\
\hline \multirow{6}{*}{$\begin{array}{l}\text { Customer } \\
\text { Satisfaction }\end{array}$} & \multirow{2}{*}{ Less Complaint } & $\mathrm{CS} 1$ & 0,728 & & Valid & 0,973 & & Reliable \\
\hline & & $\mathrm{CS} 2$ & 0,789 & & Valid & 0,973 & & Reliable \\
\hline & \multirow{2}{*}{ Service quality } & $\mathrm{CS} 3$ & 0,843 & & Valid & 0,972 & & Reliable \\
\hline & & $\mathrm{CS} 4$ & 0,782 & & Valid & 0,973 & & Reliable \\
\hline & \multirow{2}{*}{$\begin{array}{l}\text { Fullfilment } \\
\text { response }\end{array}$} & CS5 & 0,799 & & Valid & 0,973 & & Reliable \\
\hline & & CS6 & 0,756 & & Valid & 0,973 & & Reliable \\
\hline \multirow{6}{*}{$\begin{array}{l}\text { Customer } \\
\text { Loyalty }\end{array}$} & \multirow{2}{*}{ Repeat order } & CL1 & 0,756 & & Valid & 0,973 & & Reliable \\
\hline & & CL2 & 0,612 & & Valid & 0,973 & & Reliable \\
\hline & \multirow{2}{*}{ Recomendation } & CL3 & 0,746 & & Valid & 0,973 & & Reliable \\
\hline & & CL4 & 0,757 & & Valid & 0,974 & & Reliable \\
\hline & \multirow{2}{*}{ Retention } & CL5 & 0,778 & & Valid & 0,973 & & Reliable \\
\hline & & CL6 & 0,709 & & Valid & 0,973 & & Reliable \\
\hline
\end{tabular}




\section{Measurement Outer Model}

In measuring the outer model using convergent validity with Average Varince Extracted (AVE > 0.5). For Realibility using Composite Reliability and Cronbach Alpha $>0.6$. The results can be seen in the Table 3 below.

Table 3. Summary for Reflective Measurement Models Source: Smart PL

\begin{tabular}{|c|c|c|c|c|c|c|}
\hline \multirow{3}{*}{$\begin{array}{l}\text { Latent } \\
\text { Variable }\end{array}$} & \multirow{3}{*}{ Indicators } & \multicolumn{2}{|c|}{$\begin{array}{c}\text { Internal Consistency } \\
\text { Reliability }\end{array}$} & \multicolumn{2}{|c|}{$\begin{array}{l}\text { Convergent } \\
\text { Validity }\end{array}$} & \multirow{3}{*}{$\begin{array}{c}\text { Discriminant Validity } \\
\text { HTMT confidence } \\
\text { interval doesn't } \\
\text { include1 }\end{array}$} \\
\hline & & $\begin{array}{l}\text { Composite } \\
\text { Reliability }\end{array}$ & \begin{tabular}{|c|} 
Cronbach \\
Alpha \\
\end{tabular} & Loadings & AVE & \\
\hline & & $>0.6$ & $>0.6$ & $>0.7$ & 0.5 & \\
\hline \multirow{6}{*}{$\begin{array}{l}\text { Technical } \\
\text { Competency }\end{array}$} & $\mathrm{TC} 1$ & \multirow{6}{*}{0.911} & \multirow{6}{*}{0.882} & 0.821 & \multirow{6}{*}{0.63} & Yes \\
\hline & $\mathrm{TC} 2$ & & & 0.786 & & Yes \\
\hline & $\mathrm{TC} 3$ & & & 0.765 & & Yes \\
\hline & $\mathrm{TC} 4$ & & & 0.792 & & Yes \\
\hline & $\mathrm{TC} 5$ & & & 0.813 & & Yes \\
\hline & TC6 & & & 0.784 & & Yes \\
\hline \multirow{6}{*}{$\begin{array}{c}\text { Relational } \\
\text { Capabilities }\end{array}$} & $\mathrm{RC} 1$ & \multirow{6}{*}{0.930} & \multirow{6}{*}{0.909} & 0.836 & \multirow{6}{*}{0.688} & Yes \\
\hline & $\mathrm{RC} 2$ & & & 0.869 & & Yes \\
\hline & $\mathrm{RC} 3$ & & & 0.858 & & Yes \\
\hline & $\mathrm{RC} 4$ & & & 0.819 & & Yes \\
\hline & $\mathrm{RC} 5$ & & & 0.781 & & Yes \\
\hline & $\mathrm{RC} 6$ & & & 0.810 & & Yes \\
\hline \multirow{6}{*}{$\begin{array}{l}\text { Cognitive } \\
\text { Ability }\end{array}$} & CA1 & \multirow{6}{*}{0.929} & \multirow{6}{*}{0.909} & 0.779 & \multirow{6}{*}{0.687} & Yes \\
\hline & $\mathrm{CA} 2$ & & & 0.823 & & Yes \\
\hline & CA3 & & & 0.877 & & Yes \\
\hline & $\mathrm{CA} 4$ & & & 0.837 & & Yes \\
\hline & CA5 & & & 0.847 & & Yes \\
\hline & CA6 & & & 0.807 & & Yes \\
\hline \multirow{6}{*}{$\begin{array}{l}\text { Customer } \\
\text { Satisfaction }\end{array}$} & CS1 & \multirow{6}{*}{0.934} & \multirow{6}{*}{0.915} & 0.764 & \multirow{6}{*}{0.703} & Yes \\
\hline & $\mathrm{CS} 2$ & & & 0.848 & & Yes \\
\hline & CS3 & & & 0.893 & & Yes \\
\hline & CS4 & & & 0.830 & & Yes \\
\hline & CS5 & & & 0.870 & & Yes \\
\hline & CS6 & & & 0.819 & & Yes \\
\hline \multirow{6}{*}{$\begin{array}{l}\text { Customer } \\
\text { Loyalty }\end{array}$} & CL1 & \multirow{6}{*}{0.923} & \multirow{6}{*}{0.900} & 0.801 & \multirow{6}{*}{0.668} & Yes \\
\hline & CL2 & & & 0.733 & & Yes \\
\hline & CL3 & & & 0.844 & & Yes \\
\hline & CL4 & & & 0.868 & & Yes \\
\hline & CL5 & & & 0.867 & & Yes \\
\hline & CL6 & & & 0.784 & & Yes \\
\hline
\end{tabular}




\section{Measurement Inner Model}

The value of $\mathrm{R}$ Square on the endogenous construct is based on (Hair Jr. et al., 2017) $\mathrm{R}^{2}$, with $0.75,0.50,0.25$, respectively, describing substantial, moderate, or weak levels of predictive accuracy.

Table 4. R2 Value Result

Source: Smart PLS

\begin{tabular}{lccc}
\hline & R Square & $\begin{array}{c}\text { R Square } \\
\text { Adjusted }\end{array}$ & Remark \\
\hline Customer Satisfaction & 0.799 & 0.755 & Subtantial \\
\hline Customer Loyalty & 0.703 & 0.702 & Subtantial \\
\hline
\end{tabular}

\section{Hypothesis Testing Result \& Analysis}

The results of the relationship between these variables are analyzed using t-values for assesment one side 1.96 at the 0.05 significance level (Hair et al., 2014). For significant results the T-Statistics must be above 1.96 and for significant levels it must be less than 0.05 . The following Table 5 which is the result of hypothesis testing using Smart PLS with bootstrapping 500 sub samples.

Table 5. Final Results (Mean, STDEV, T-Values, P-Values)

Source: Smart PLS

\begin{tabular}{lccccc}
\hline & $\begin{array}{c}\text { Origina } \\
\text { Sample } \\
(\mathrm{O})\end{array}$ & $\begin{array}{c}\text { Sample } \\
\text { Mean } \\
(\mathrm{M})\end{array}$ & $\begin{array}{c}\text { Standard } \\
\text { Deviation } \\
(\text { STDEV })\end{array}$ & $\mid$ O/STDEV|) & Values \\
\hline $\begin{array}{l}\text { Technical Competency -> Customer } \\
\text { Satisfaction }\end{array}$ & 0.190 & 0.196 & 0.068 & 2.810 & 0.005 \\
\hline $\begin{array}{l}\text { Relational Capability -> Customer } \\
\text { Satisfaction }\end{array}$ & 0.111 & 0.115 & 0.081 & 1.369 & 0.172 \\
\hline $\begin{array}{l}\text { Cognitive Ability -> Customer } \\
\text { Satisfaction }\end{array}$ & 0.619 & 0.612 & 0.080 & 7.715 & 0.000 \\
\hline $\begin{array}{l}\text { Customer Satisfaction -> Customer } \\
\text { Loyalty }\end{array}$ & 0.839 & 0.840 & 0.025 & 33.365 & 0.000 \\
\hline
\end{tabular}

\section{Hypothesis \#1}

HO: Technical Competency has a not significant impact on Customer Satisfaction H1: Technical Competency has a significant impact on Customer Satisfaction

According to Table 5, it shown the impact between Technical Competency and Customer Satisfaction is significant impact. The results show the $\mathrm{P}$ Value or statistical research error is $0.005(\mathrm{P}<0.05$ significant levels) and $(\mathrm{T}$ - statistics $=2.81)>1.96$. Compared to Relational Capability and
Cognitive Ability, Technical Competency has second priority in relation to its impact on customer satisfaction. The indicator that has the most impact on the Technical Competency variable is TC1 or Skill, while the lowest impact is Knowledge.

\section{Hypothesis \#2}

H0: Relational Capabilities has a not significant impact on Customer Satisfaction H1: Relational Capabilities has a significant impact on Customer Satisfaction 
Based on Table 5, it demonstrates the impact between Relational Capabilities and Customer Satisfaction is not significant effect but positive. The results show the $\mathrm{P}$ Value is $0.172(\mathrm{P}>0.05$ significant levels $)$ and $(\mathrm{T}$ - statistics $=1.36)<1.96$. Compared to other independent variables, it turns out that relational capability is the variable with the last priority. Although the impact on customer satisfaction is not significant, there is still a high assessment of the knowledge sharing indicator.

\section{Hypothesis \#3}

H0: Cognitive Ability has a not significant impact on Customer Satisfaction

H1: Cognitive Ability has a significant impact on Customer Satisfaction

According to Table 5, it shown the impact between Cognitive Ability and Customer Satisfaction is significant. The results show the $\mathrm{P}$ Value is $0.000(\mathrm{P}<0.05$ significant levels) and ( $\mathrm{T}$ - statistics $=7.71)>1.96$. Cognitive Ability is an independent variable that has the highest influence on customer satisfaction. Especially the capacity to learn indicator which has the highest score.

\section{Hypothesis \#4}

HO: Customer Satisfaction has a not significant impact on Customer Loyalty H1: Customer Satisfaction has a significant impact on Customer Loyalty

According to Table 5, it shown the impact between Customer Satisfaction and Customer Loyalty is significant. The results show the $\mathrm{P}$ Value is $0.000(\mathrm{P}<0.05$ significant levels) and ( $\mathrm{T}$ - statistics $=33.36)$ $>$ 1.96. The results of this hypothesis test are very much in accordance with previous research (Ngo and Nguyen, 2016) and strengthen the test results because previously the path coefficient was 0.744 now 0.839 . The most influential indicator on customer satisfaction is service quality.
From four hypotheses, three of them were accepted and one hypothesis which is relational capabilities has a significant impact on Customer Satisfaction were rejected.

\section{Conclusion}

Based on the results and data analysis carried out in result, the objective is to determine the significant influence of Technical Competence, Relational Ability and Cognitive Ability on Customer Satisfaction that affects Customer Loyalty. Several conclusions can be drawn below:

1. Technical Competency has a positive significant impact on Customer Satisfaction, meaning that if the technical competency possessed by mechanics is good, customer satisfaction will be good.

2. Relational Capability does not have a significant impact on Customer Satisfaction is mean that if the Relational Capability possessed by a mechanic is good, that is not enough to make customers satisfied.

3. Cognitive Ability has a positive significant impact on Customer Satisfaction, meaning that if the Cognitive Ability possessed by the mechanic is good then customer satisfaction will be good and compared to technical competency, this is what customers expect the most.

4. Customer Satisfaction has a significant impact on customer loyalty, this is what makes customers repeat orders and can recommend repair and maintenance services for heavy equipment carried out by UT mechanics.

\section{Recomendation for Further Study}

First, future research can apply the same model in other types of industries, especially in the service sector, but added with interviews with several companies representing their segments; low, medium and large. Second, variables related to dynamic capabilities are likely to develop, so they need to be updated according to the times. 


\section{References}

Adner, R. \& Helfat, C. E. (2003). Corporate effects and dynamic managerial capabilities. Strategic Management Journal, 24(10), pp. 1011-1025. https://doi.org/10.1002/smj.331.

Ajao, R., Ikechukwu, I. \& Olusola, A. (2012). Is customer satisfaction an indicator of customer loyalty?. Australian Journal of Business and Management Research, 2(07), pp. 1420.

Angelova, B. \& Zekiri, J. (2011). Measuring customer satisfaction with service quality using american customer satisfaction model (ACSI model). International Journal of Academic Research in Business and Social Sciences, 1(3), p. 27. https://doi.org/10.6007/ijarbss.v1i2.35.

Denis, P. L. \& Gilbert, F. (2012). The effect of time constraints and personality facets on general cognitive ability (GCA) assessment. Personality and Individual Differences, 52(4), pp. 541545. https://doi.org/10.1016/j.paid. 2011 .11.024.

Flint, D. J., Blocker, C. P. \& Boutin, P. J. (2011). Customer value anticipation, customer satisfaction and loyalty: An empirical examination. Industrial Marketing Management, 40(2), pp. 219-230. https://doi.org/10.1016/j. indmarman. 2010.06.034.

Hair, J. F., Sarstedt, M., Hopkins, L., \& Kuppelwieser, V. G. (2014). Partial least squares structural equation modeling (PLS-SEM): An emerging tool in business research. European Business Review, 26(2), pp. 106-121. https://doi.org/10.1108/EBR-10-20130128 .
Hair, J. F., Matthews, L. M., Matthews, R. L. \& Sarstedt, M. (2017). PLS-SEM or CB-SEM: Updated guidelines on which method to use. International Journal of Multivariate Data Analysis, 1(2), p. 107 . https://doi.org/10 .1504 /ijmda .2017.1000 8574.

Hamzah, A. \& Shamsudin, M. (2020). Why customer satisfaction is important to business?. Journal of Undergraduate Social Science and Technology, 2(1), pp. 1-14. Available at: http://blog .clientheartbeat.com/ why-customersatisfaction-is-important/.

Ilieska, K. (2013). Customer satisfaction index - as a base for strategic marketing management. TEM Journal, 2(4), pp. 327-331.

Khuzainey, I. Nopiah, Z. M., Rasul, M. M. (2020). Technical competency among vocational teachers in Malaysian public skills training institutions: Measurement model validation using PLS-SEM. Journal of Technical Education and Training, 12(1), pp. 163-175 https://doi.org/10.30880/jtet .2020.12 .01.017.

Lambert, B., Plank, R. E., Reid, D. A. \& Fleming, D. (2014). A competency model for entry level business-tobusiness services sales people. Services Marketing Quarterly, 35(1), pp. 84103. https://doi.org/10.1080/ 15332969 .2014.856746.

Macnamara, B. N., Moore, A. B., Kegl, J. A. \& Conway, A. R. A. (2011). Domain-general cognitive abilities and simultaneous interpreting skill. Interpreting, 13(1), pp. 121-142. https://doi.org/10.1075/intp.13.1.08ma c. 
Ngo, M. V. \& Nguyen, H. H. (2016). The relationship between service quality, customer satisfaction and customer loyalty: An investigation in Vietnamese retail banking sector. Journal of Competitiveness, 8(2), pp. 103-116. https://doi.org/10.7441/joc.2016.02.08

Ngugi, I. K., Johnsen, R. E. \& Erdélyi, P. (2010). Relational capabilities for value co-creation and innovation in SMEs. Journal of Small Business and Enterprise Development, 17(2), pp. 260-278. https://doi.org/10.1108/ 14626001011041256.

Sekaran, U. \& Bougie, R. (2017). Research methods for business a skill-building approach. Chichester: John Wiley.

Smirnova, M., Naudé, P., Henneberg, S. C., Mouzas, S., Kouchtcha, S. P. (2011). The impact of market orientation on the development of relational capabilities and performance outcomes: The case of Russian industrial firms. Industrial Marketing Management, 40(1), pp. 4453. https://doi.org/10.1016/j. indmar man. 2010.09.009.
Toledo, A. H., Flikkema, R. and ToledoPereyra, L. H. (2011). Developing the research hypothesis. Journal of Investigative Surgery, 24(5), pp. 191$194 . \quad$ https://doi.org/10.3109/ 08941939.2011.609449.

Wang, J., Zhao, M. and Zhao, G. (2017). The impact of customer cognitive competence on online service decisionmaking: An event-related potentials perspective. Service Industries Journal, 37(5-6), pp. 363-380. https://doi.org/10.1080/02642069.201 7. 1325467.

Yaman, S. K., Abdullah, A. H., Mohammad, H., \& Hassan, F. (2015). Technical competency of construction manager in Malaysian construction industry. Applied Mechanics and Materials, 773-774, pp. 1053-1059. https://doi.org/10.4028/www.scientific .net/amm.773-774.1053 